\title{
Elk and cattle forage use under a specialized grazing system
}

\author{
LACEY E. HALSTEAD ${ }^{1}$, LARRY D. HOWERY, GEORGE B. RUYLE, PAUL R. KRAUSMAN, AND \\ ROBERT J. STEIDL
}

Authors are former Graduate Research Assistant, Associate Professor and Range Management Specialist, Professor and Range Management Specialist, Professor, and Assistant Professor, School of Renewable Natural Resources, The University of Arizona, Tucson, Ariz. 85721. 'Current address: The Nature Conservancy of Texas, P.O. Box 1440, San Antonio, Tex. 78295-1440.

\begin{abstract}
The Walker Basin Allotment grazing system in central Arizona is designed to allocate resource use under elk (Cervus elaphus $\mathbf{L}$.) and cattle (Bos taurus L.) grazing. The grazing system was designed to promote biologically acceptable levels of forage use on the half of the allotment scheduled for cattle grazing and to rest the other half by attracting elk to pastures recently grazed by cattle. The objectives of our 2-year study were to determine whether the grazing system facilitated proper forage use as defined by recent forage use and residual stubble height guidelines (i.e., 30 to $40 \%$ use and an 8- to $10-\mathrm{cm}$ stubble height) and whether the system rested one half of the allotment from elk and cattle grazing. Mean ( \pm SEM) total elk and cattle forage use for western wheatgrass (Pascopyrum smithii Rydb.), the key forage species, was 32 and $61 \% \pm 7$ in 1997 and 1998, respectively; corresponding mean $( \pm S E M)$ stubble heights were 11 and $10 \mathrm{~cm} \pm$ 0.6. Mean total cattle and elk forage use in $1998(61 \%)$ exceeded the 30 to $40 \%$ use guidelines. However, mean end-of-year stubble height was never below $10 \mathrm{~cm}$. The grazing system did not provide half the allotment with complete rest; elk used all study pastures. Elk use was higher in pastures with heavier tree cover and steeper terrain in both years, regardless of where cattle grazing occurred. Elk grazing patterns were apparently more dependent on tree cover and topography than any changes in forage caused by the grazing system.
\end{abstract}

Key Words: Arizona, deferred grazing, paired-plot, rest-rotation, stubble height, western wheatgrass

Specialized grazing systems have been developed that use cattle grazing as a tool to alter forage characteristics and, thereby, modify elk (Cervus elaphus L.) distribution. Such grazing systems often include elements of rest-rotation, deferment, or both (Vavra and Sheehy 1996). Improvements in forage availability, palatability, production, and/or animal performance have been suggested as advantages to using specialized grazing systems

Research was funded by a grant from The University of Arizona Agriculture Experiment Station. We acknowledge the Coconino National Forest and the Arizona Game and Fish Department for their support of this project. We would like to thank Dr. Lamar Smith and 3 anonymous reviewers for reviewing earlier drafts of this paper. We thank Matt Barnes, Alex Connley, Tom DeLiberto, Vicki Gempko, Arlo Halstead, Elizabeth Howery, Dan Koepke, and Dave Womack for assistance in the field and laboratory.

Manuscript accepted 19 Sept. 01

\section{Resumen}

El sistema de asignación del apacentamiento de la cuenca Walker, en la parte central de Arizona, esta diseñado para asignar el uso de los recursos bajo el apacentamiento de alces (Cervus elaphus L.) y ganado bovino (Bos taurus L.). El sistema de apacentamiento se diseño para promover niveles biologicamente aceptables de utilización de forraje en la mitad del terreno programado para el ganado bovino y descansar la otra mitad mediante la atracción de los alces a potreros recién apacentados por bovinos. Los objetivos de nuestro estudio, de 2 años de duración, fueron determinar si el sistema de apacentamiento facilitó el uso adecuado del forraje tal como lo definen los lineamientos recientes de uso de forraje y altura del rastrojo (esto es, 30 a $40 \%$ de uso y 8 a $10 \mathrm{~cm}$ de altura del restrojo) y si el sistema descanso del alce y bovinos una de las mitades de la asignación. La media ( \pm EEM) de uso total de forraje por alces y bovinos para el "Western wheatgrass" (Pascopyrum smithii Rydb.), la especie clave, fue 32 y $61 \% \pm 7 \%$ en 1997 y 1998 respectivamente, $y$ la medias correspondientes $( \pm$ EEM) para la atura del rastrojo fueron 11 y $10 \mathrm{~cm} \pm 0.6$. En 1998, la media total de uso de forraje por alces y bovinos $(61 \%)$ excedió el 30 a $40 \%$ de uso establecido en los lineamientos. Sin embargo, la media de altura del rastrojo al final del año nunca fue menor a $10 \mathrm{~cm}$. El sistema de apacentamiento no proveyó un descanso completo para la mitad del terreno, el alce usó todos los potreros bajo estudio. El uso por el alce fue mayor en potreros con una densa cobertura de árboles y de terreno con pendiente, sin importar donde ocurrió el apacentamiento de los bovinos. Los patrones de apacentamiento del alce aparentemente fueron más dependientes de la cobertura de árboles y la topografía del terreno que cualquier cambio en el forraje causado por el sistema de apacentamiento.

(Anderson and Scherzinger 1975, Alt et al. 1992, Wisdom and Thomas 1996). These systems may attract elk to areas recently grazed by cattle (Gordon 1988, Alt et al. 1992, Frisina 1992), or they may produce little or no change in forage production, nutritional content, or herbivore distribution (Lacey and Van Poolen 1981, Yeo et al. 1993, Wambolt et al. 1997).

The Walker Basin Allotment grazing system in central Arizona combines elements of rest-rotation and deferment, employing seasonal cattle grazing on half the allotment each year (United States Forest Service [USFS], unpublished Walker Basin Allotment Management Plan 1990, Camp Verde, Ariz.). The 
objectives of our 2-year study were to determine whether the grazing system promoted target levels of forage use and residual stubble height (Holechek et al. 1998), and whether the system rested half the allotment from large ungulate herbivory each year.

\section{Materials And Methods}

\section{Study Area}

The Walker Basin Allotment (111 ${ }^{\circ} 40^{\prime}$ $40^{\prime} \mathrm{W}, 34^{\circ} 38^{\prime} 30^{\prime} \mathrm{N}$ ) is comprised of about 31,000 ha of USFS rangeland. The Walker Basin Allotment's 57 pastures are divided into 2 main sections that run west to east along an increasing elevational gradient. The Walker Basin Allotment has 3 seasonal ranges: winter $(1,220$ to $1,524 \mathrm{~m}$ elevation), transitional $(1,525$ to $1,982 \mathrm{~m}$ elevation), and summer (1,983 to $2,287 \mathrm{~m}$ elevation). Our study area (about 6,750 ha) consisted of 4 pastures ( 850 to 2,100 ha) on the transitional range (Fig. 1) because local resource managers identified this range as having high potential for elk and cattle competition (personal communication, USFS, Arizona Game and Fish Department, and ranch managers).

Western wheatgrass (Pascopyrum smithii Rydb.) has been identified by the USFS as the key herbaceous forage species in the study pastures (USFS, unpublished Walker Basin Allotment Management Plan 1990, Camp Verde, Arizona). Other plant species included blue grama (Bouteloua gracilis H.B.K.), sideoats grama (Bouteloua curtipendula Michx.), downy brome (Bromus tectorum L.), buckwheat (Eriogonum spp.), snakeweed (Gutierrezia sarothrae Pursh.), squawbush (Rhus trilobata Nutt.), emory oak (Quercus emoryi Torr.), pinyon pine (Pinus edulis Engelm.) and juniper (Juniperus osteosperma Torr.). Soils are predominantly classified as Vertic Haplustalfs (Terrestrial Ecosystems Survey of the Coconino National Forest 1992).

The growing season (frost-free days) on the transitional range extends from March to October. Average yearly precipitation is 33 $\mathrm{cm}$, occurring primarily from December to February and July to September (National Oceanic and Atmospheric Administration 1997). Winter precipitation occurs primarily as snow. The northern pastures (1 and 2) were near an ephemeral drainage and contained more pinyon pine and juniper cover than the southern pastures ( 3 and 4 ).

\section{Description of Grazing System and Herbivores}

The Walker Basin Allotment grazing system is designed to promote biologically acceptable levels of forage use by cattle, elk, and other wild herbivores and to rest half of the allotment by attracting elk and other wild ungulates to pastures recently grazed by cattle (USFS, unpublished Walker Basin Allotment Management Plan 1990, Camp Verde, Ariz.). Hereford and Hereford cross-bred (Saler, Braford, Brahman, Angus, Gelbvieh) cow-calf pairs were used in this experiment and handled following the University of Arizona's Animal Care Protocol \# 96-118. During 1997, 413 cow-calf pairs were used (mean body weight $=476 \mathrm{~kg} \pm 62$ $\mathrm{SD}$ ), while $450 \mathrm{cow}$-calf pairs were used in 1998 (mean body weight $=457 \mathrm{~kg} \pm 87$ SD). Each year, cattle were moved up the elevational gradient through pastures on one half of the allotment during the growing season (about 14 days/pasture) and moved down the elevational gradient on the same half during the dormant season (about 5 days/grazed pasture). The other half of the allotment was rested from cattle grazing the entire year (i.e., rested pastures). Seasonal cattle grazing is used to increase palatable regrowth, which is hypothesized to attract elk to pastures recently grazed by cattle, thereby resting the other half of the allotment from cattle and elk herbivory.

According to the Arizona Game and Fish Department, elk is the main wild herbivore species that significantly impacts western wheatgrass, the key forage species used in this study. Jack rabbits (Lepus californicus Gray), pronghorn (Antilocapra americana Ord), mule deer (Odocoileus hemionus Rafinesque), and white-tailed deer (Odocoileus virginianus Rafinesque) are thought to use insignificant amounts of western wheatgrass compared with elk and cattle due to lower animal numbers or dietary differences (Thomas Britt, Regional Supervisor, Arizona Game and Fish Department, personal communication, Vavra et al. 1989). Thus, our research focused on elk and cattle impacts on western wheatgrass.

\section{General Sampling Procedures}

The study was conducted from March 1997 to October 1998. We estimated forage use by elk and cattle and residual stubble height during 2 growing seasons. The southern pastures ( 3 and 4) were grazed by cattle in 1997 and the northern pastures (1 and 2) were grazed by cattle in 1998 as required by the USFS grazing management plan (Fig. 1). Average stocking rates for cattle, calculated using definition ' $a$ ' of the Glossary Revision Special Committee report (1989), were 5.1 and 6.9 ha/AUM during 1997 and 1998, respectively (Fig. 1). All pastures were accessible to elk during the entire study.

Paired-plot and stubble height techniques (Interagency Technical Reference 1996) were used to evaluate grazing of western wheatgrass in 12 randomly selected 3-ha sampling areas (3/pasture). Each sampling area was located $\geq 0.4 \mathrm{~km}$ from well-traveled roads, fences, and water and $\geq 0.3 \mathrm{~km}$ from adjacent sampling areas. Sampling areas contained 6 paired-plot units. Each paired-plot unit consisted of 1 protected macroplot $\left(1.7-\mathrm{m}^{2}\right.$ grazing exclosure), and two, $1.7-\mathrm{m}^{2}$ unprotected macroplots, for a total of 72 protected and

\section{$\mathbf{N} \uparrow$}

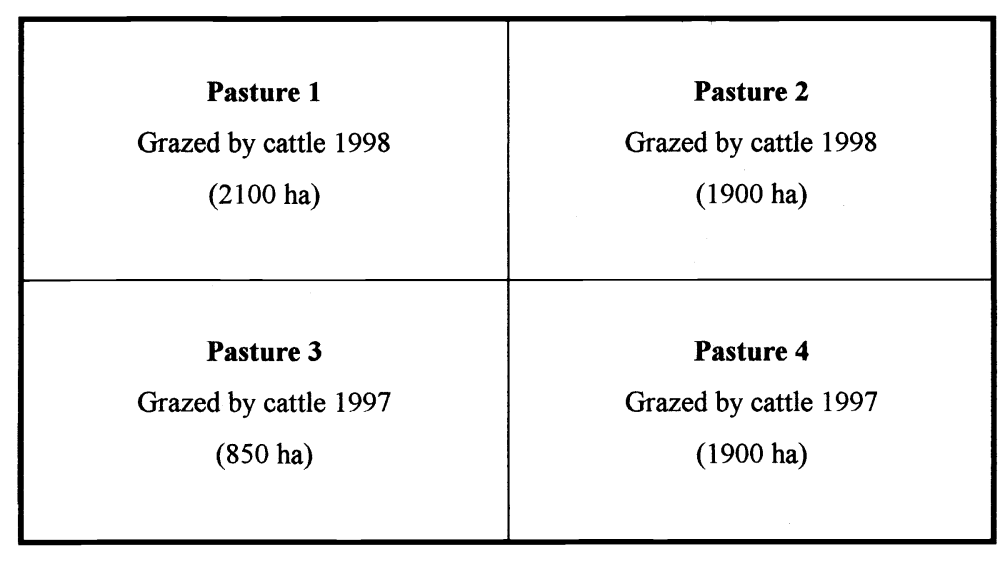

Fig. 1. Study pasture layout on the Walker Basin Allotment, central Arizona. Cattle grazed southern pastures ( 3 and 4) Jun./Jul. and Nov. of 1997, and northern pastures (1 and 2) Jun./Jul. and Nov. of 1998. Elk had access to study pastures year-round. 
144 unprotected plots in the study area (i.e., 72 paired-plot units). Two unprotected macroplots, rather than the traditional 1 , were matched with each protected macroplot to account for possible patch grazing by cattle and elk (Klingman et al. 1943, Grelen 1967). Unprotected and protected macroplots were matched based on similar ocular estimates of western wheatgrass phytomass. Each sampling area also contained a 400-m stubble height transect located between protected and unprotected macroplots and $\geq 10 \mathrm{~m}$ from protected macroplots.

To avoid attracting animals to protected plots within sampling areas, each protected plot was $\geq 100 \mathrm{~m}$ from the others. Protected and unprotected plots were $\geq 50$ $\mathrm{m}$ apart, and unprotected plots within a paired-plot unit were $\geq 10 \mathrm{~m}$ apart. To minimize bias due to enhanced growth within protected plots, new paired-plot units were established in March each year (Owensby 1969). Before initially establishing paired-plot units, we tested the precision of ocular matching by clipping, drying, and weighing western wheatgrass from 29 pairs of $0.25-\mathrm{m}^{2}$ circular plots that were later used to clip subsamples within paired-plot units. A paired t-test revealed no difference between paired test plots $(\mathrm{P}$ $>0.2, \alpha=0.05)$. The same observer always established paired-plot units.

We estimated forage use and stubble height in each pasture in 3 sampling periods: 1) immediately before cattle entered grazed pastures, 2) immediately after cattle exited grazed pastures, and 3) at the end of the growing season, about 3-4 months after cattle exited grazed pastures (Fig. 2 and Fig. 3; Tables 1 and 2). Measurements made before cattle grazed (early/mid-June) estimated relative elk use in all pastures. Measurements made after cattle grazed (mid-June/early July) estimated relative cattle and/or elk use, while measurements made at the end of the growing season (mid-October) estimated total forage use for the entire growing season (cattle and/or elk). Relative use describes the amount of forage consumed or destroyed up to a certain time during the growing season but prior to peak standing crop (e.g., June or July; Frost et al. 1994). Total forage use is "the proportion of current year's forage consumed or destroyed by grazing animals," measured at the end of the growing season (Glossary Revision Special Committee 1989). Cattle grazed study pastures about 5 days in midNovember (dormant season), and elk migrating to winter ranges likely used study pastures at this time. However, we

Table 1. Mean relative and total western wheatgrass forage use (\%) under 2 treatments (elk grazing and elk/cattle grazing) across 3 sampling periods on the Walker Basin Allotment, central Arizona, 1997/1998 (SEM = 7).

\begin{tabular}{|c|c|c|c|c|}
\hline \multirow[b]{2}{*}{ Year/Grazing animal ${ }^{2}$} & \multirow[b]{2}{*}{ Pasture } & \multicolumn{3}{|c|}{ Sampling period $^{1}$} \\
\hline & & $\begin{array}{l}\text { Before cattle } \\
\text { grazing }\end{array}$ & $\begin{array}{c}\text { After cattle } \\
\text { grazing }\end{array}$ & $\begin{array}{c}\text { End of } \\
\text { growing season }\end{array}$ \\
\hline & & \multicolumn{3}{|c|}{ 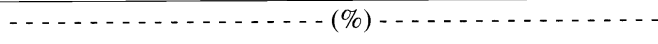 } \\
\hline \multicolumn{5}{|l|}{1997} \\
\hline Elk & 1 and 2 & 28 & 26 & 22 \\
\hline Elk and cattle & 3 and 4 & 14 & 37 & 32 \\
\hline \multicolumn{5}{|l|}{1998} \\
\hline Elk and cattle & 1 and 2 & 28 & 58 & 61 \\
\hline Elk & 3 and 4 & 13 & 23 & 26 \\
\hline
\end{tabular}

${ }^{\mathrm{I}}$ Before cattle grazing = relative forage use, early/mid-Jun.; After cattle grazing = relative forage use, mid-Jun./early Jul.; End of growing season, or 3 to 4 months after cattle exited grazed pastures = total forage use, mid-Oct.

${ }^{2}$ Year and grazing animal main effects were significant and are reported in the Results section and Figs. 2a,2b.

did not measure dormant season grazing because of snow depth.

\section{Paired-plot Sampling}

For each sampling period, we clipped western wheatgrass from 2 randomly selected paired-plot units in each sampling area within each pasture for a total of 24 paired-plot samples. All plots were clipped to ground level. During 1997, we used a $0.25-\mathrm{m}^{2}$ circular frame to clip 4 subplots within each $1.7-\mathrm{m}^{2}$ macroplot. We averaged the 4 subplot dry weights to obtain 1 mean protected weight for each protected macroplot. For the 2 corresponding unprotected macroplots, we averaged the 8 subplot dry weights (4 subplots $\mathrm{x} 2$ macroplots) to obtain 1 mean unprotected weight. Percentage use for a paired-plot unit was the ratio of the mean unprotected and protected weights. Negative utilization values from paired-plot units were zeroed (Werner and Urness 1998). Mean use for a sampling area was calculated from the 2 randomly selected paired-plot units. Mean use for each pasture treatment (grazed or rested) was calculated across the appropri-

Table 2. Mean western wheatgrass residual stubble height $(\mathrm{cm})$ under 2 treatments (elk grazing and elk/cattle grazing) across 3 sampling periods on the Walker Basin Allotment, central Arizona, 1997/1998 $(\mathrm{SEM}=\mathbf{0 . 6})$.

\begin{tabular}{|c|c|c|c|c|}
\hline \multirow[b]{2}{*}{ Year/Grazing animal $^{2}$} & \multirow[b]{2}{*}{ Pasture } & \multicolumn{3}{|c|}{ Sampling period $^{1}$} \\
\hline & & $\begin{array}{l}\text { Before cattle } \\
\text { grazing }\end{array}$ & $\begin{array}{l}\text { After cattle } \\
\text { grazing }\end{array}$ & $\begin{array}{c}\text { End of } \\
\text { growing season }\end{array}$ \\
\hline & & \multicolumn{3}{|c|}{ 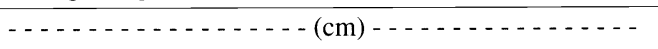 } \\
\hline \multicolumn{5}{|l|}{1997} \\
\hline Elk & 1 and 2 & 12 & 10 & 12 \\
\hline Elk and cattle & 3 and 4 & 13 & 10 & 11 \\
\hline \multicolumn{5}{|l|}{1998} \\
\hline Elk and cattle & 1 and 2 & 16 & 14 & 10 \\
\hline Elk & 3 and 4 & 17 & 16 & 12 \\
\hline
\end{tabular}

${ }^{1}$ Before cattle grazing $=$ relative forage use, early/mid-Jun.; After cattle grazing = relative forage use, mid-Jun./early Jul.; End of growing season, or 3 to 4 months after cattle exited grazed pastures = total forage use, mid-Oct.

${ }^{2}$ Year and grazing animal main effects were significant and are reported in the Results section and Figs. 3a,3b. 


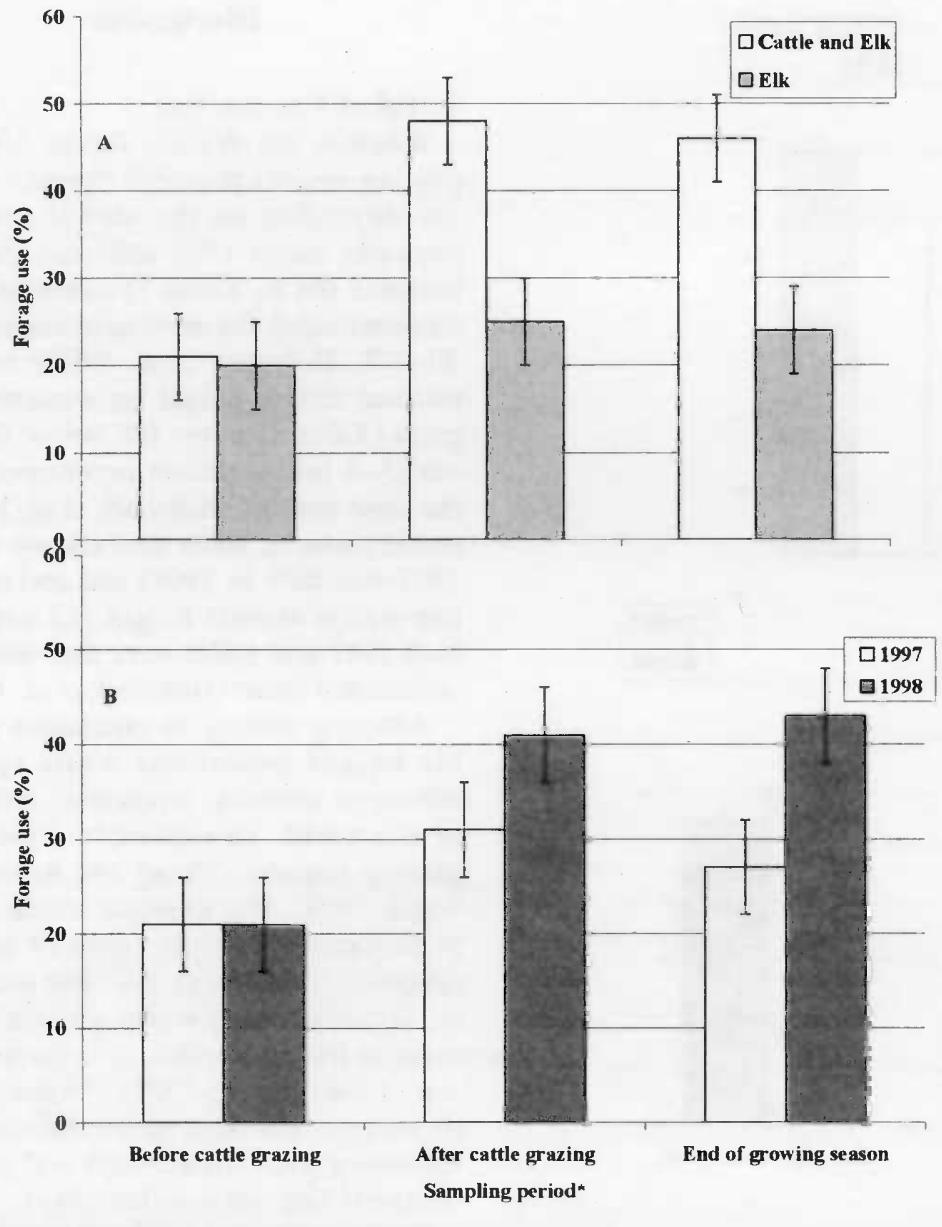

Fig. 2. Grazing animal (A) and year (B) effects on relative and total western wheatgrass forage use (\%) across 3 sampling periods on the Walker Basin Allotment, central Arizona (SEM = 5). " Sampling periods were: Before cattle grazing = relative forage use, early/midJun.; After cattle grazing = relative forage use, mid-Jun./early Jul.; End of growing season, or 3 to 4 months after cattle exited grazed pastures = total forage use, mid-Oct.

\section{Stubble Height Sampling}

Stubble height sampling methodology was the same in both years. For each sampling period, the average height of 60 individual western wheatgrass plants was measured (Interagency Technical Reference 1996). Individual plants (grazed and ungrazed) were measured as encountered at approximate $3-\mathrm{m}$ intervals along a transect. An individual western wheatgrass plant was defined as a turf of vegetation occupying a circle at least $5 \mathrm{~cm}$ in diameter. Height of the extended green leaf area of each plant was measured to the nearest 0.5 $\mathrm{cm}$ after gently placing a ruler in the middle of the turf circle. When a plant was grazed unevenly, we ocularly estimated the average height of the $5-\mathrm{cm}$ turf area. Mean residual stubble height for each sampling area was calculated from the 60 plants, and mean residual stubble height for pastures was calculated as described for paired-plot estimates.

\section{Statistical Analyses}

We employed a completely randomized design experiment with $2 \times 2$ factorial arrangement of treatments. Because we measured forage use of western wheatgrass and residual stubble height repeatedly in sampling areas, we used a multivariate repeated measures analysis of variance to test the effects of grazing animal (elk vs elk and cattle), year (1997 vs 1998), and grazing animal $x$ year interaction. We applied an arc-sine transformation to forage-use data prior to analysis (Steel and Torrie 1980)

\section{Results}

Forage use was influenced by type of grazing animal (Fig. 2A; $\mathrm{F}_{2,19}=6.1 ; \mathrm{P}=$ 0.009) and year (Fig. 2B; $\mathrm{F}_{2,19}=2.9 ; \mathrm{P}=$ 0.08 ) and there was no type of animal $x$

\section{Forage Use}

year interaction $(P>0.9)$. On average, elk had used about $20 \%$ (relative use) of western wheatgrass in pastures scheduled for grazing and rest before cattle were released into the study area (Fig. 2A). In rested pastures (elk use), forage use measured after cattle grazing, and at the end of the growing season, averaged $25 \%$ (relative use) and $24 \%$ (total use), respectively, while corresponding use in grazed pastures (cattle and elk use) averaged $48 \%$ (relative use) and $46 \%$ (total use). Total forage use averaged 22 percentage points higher in grazed pastures $(46 \%)$ than in rested pastures $(24 \%)$ at the end of the growing season.

Relative forage use attributable to elk averaged about $20 \%$ before cattle arrived in the study area both years of the study (Fig. 2B). However, forage use measured after cattle grazing and at the end of the growing season averaged 10 and 16 percentage points higher in 1998 than in 1997, respectively.

\section{Residual Stubble Height}

Residual stubble height also was influenced by type of grazing animal (Fig. 3A; $\mathrm{F}_{2,19}=3.6 ; \mathrm{P}=0.06$ ) and year (Fig. 3B; $\left.\mathrm{F}_{2,19}=32.2 ; \mathrm{P}<0.0001\right)$, and there was no type of animal $\mathrm{x}$ year interaction $(\mathrm{P}>$ $0.8)$. Stubble height averaged $14 \mathrm{~cm}$ in pastures scheduled for grazing and rest before cattle arrived at the study area (Fig. $3 \mathrm{~A}$ ). In grazed pastures (cattle and elk use), mean stubble height decreased to 12 $\mathrm{cm}$ after cattle grazing and to $10 \mathrm{~cm}$ at the end of the growing season, compared with 13 and $12 \mathrm{~cm}$ in rested pastures (elk use), respectively, during those same sampling periods. Stubble heights averaged $2 \mathrm{~cm}$ lower in grazed pastures $(10 \mathrm{~cm})$ than in rested pastures $(12 \mathrm{~cm})$ by the end of the growing season.

In 1997, stubble heights, measured before cattle grazing $(12 \mathrm{~cm})$ and after cattle grazing $(10 \mathrm{~cm})$, averaged 4 and $5 \mathrm{~cm}$ lower than respective 1998 stubble heights (i.e., 16 and $15 \mathrm{~cm}$; Fig. 3B). However, stubble height averaged about the same by the end of the growing season for both years of the study (i.e., 12 and $11 \mathrm{~cm}$ in 1997 and 1998, respectively).

\section{Elk and Cattle Grazing Patterns}

Because it is important to discuss both relative and total forage use in relation to corresponding stubble heights across sampling periods, we tabulated results by year and grazing treatment (Tables 1 and 2). Higher use levels occurred after cattle had occupied grazed pastures (cattle and elk use), which typically yielded lower stub- 

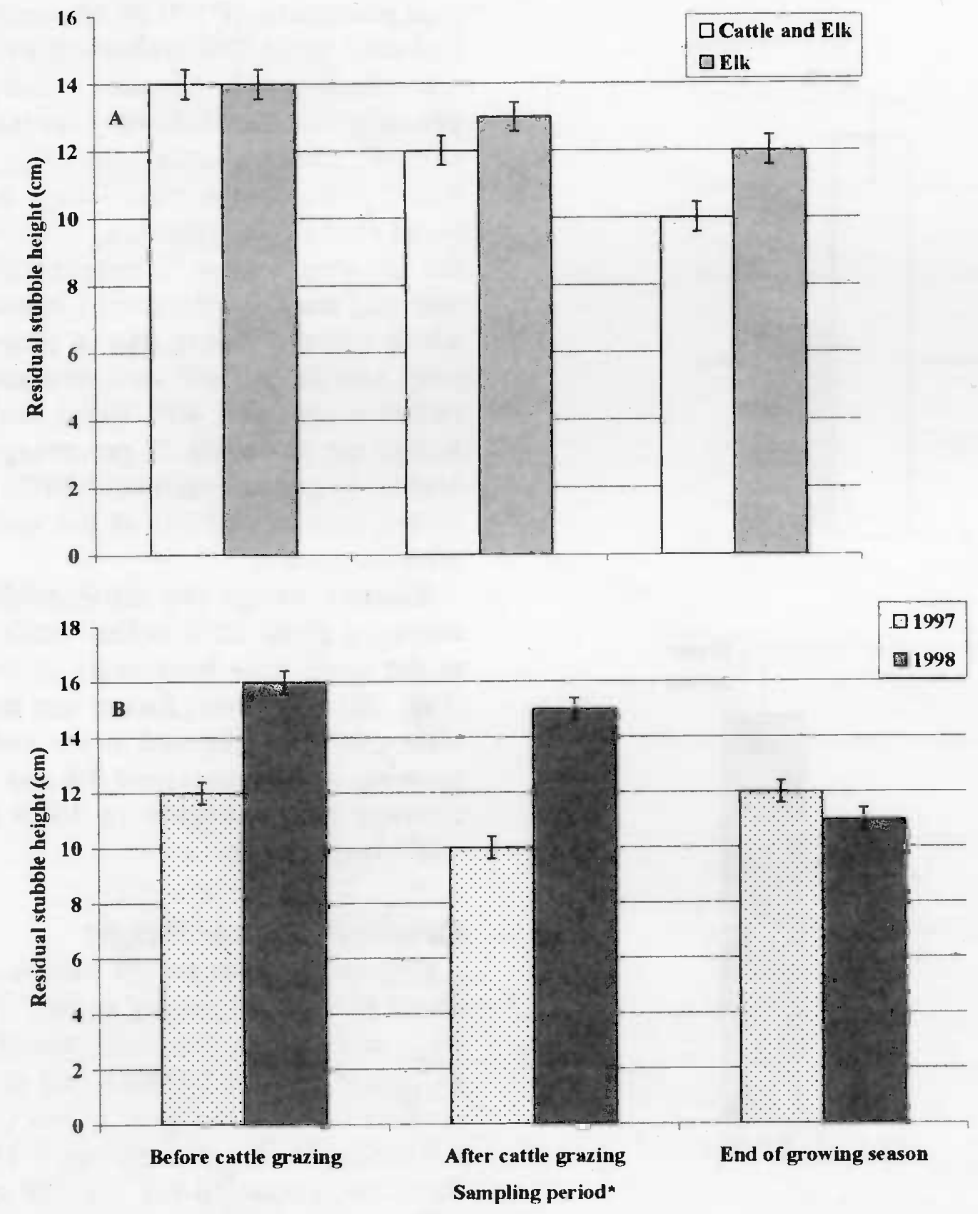

Fig. 3. Grazing animal (A) and year (B) effects on western wheatgrass stubble height $(\mathrm{cm})$ across 3 sampling periods on the Walker Basin Allotment, central Arizona $(\mathrm{SEM}=\mathbf{0 . 4}){ }^{*}$ Sampling periods were: Before cattle grazing = relative forage use, early/mid-Jun.; After cattle grazing = relative forage use, mid-Jun./early Jul.; End of growing season, or 3 to 4 months after cattle exited grazed pastures $=$ total forage use, mid-Oct.

ble heights compared with rested pastures (elk use) during both years of the study (Tables 1 and 2). As expected, mean forage use in grazed pastures was higher after cattle grazing ( 37 and $58 \%$ relative forage use during 1997 and 1998, respectively), and at the end of the growing season (32 and $61 \%$ total forage use during 1997 and 1998 , respectively), than before cattle grazing (14 and $28 \%$ relative forage use during 1997 and 1998, respectively; Table 1).

Corresponding mean stubble heights in grazed pastures were lower after cattle grazing (10 and $14 \mathrm{~cm}$ during 1997 and 1998 , respectively), and at the end of the growing season (11 and $10 \mathrm{~cm}$ during 1997 and 1998, respectively), than before cattle grazing (13 and $16 \mathrm{~cm}$ during 1997 and 1998, respectively; Table 2). Interestingly, stubble height at the end of the growing season was about the same both years of the study regardless of grazing treatment (i.e., range $=10-12 \mathrm{~cm}$;
Table 2), whereas estimates of total forage use (Table 1) were much higher in grazed pastures during $1998(61 \% \pm 7)$ than in $1997(32 \% \pm 7)$. Higher overall stubble height in 1998 was correlated with higher mean western wheatgrass standing crop (i.e., 277 vs. $471 \mathrm{~kg} \mathrm{ha}^{-1}$ in 1997 and 1998, respectively, SEM = 32). Higher production levels in 1998 apparently allowed higher total forage use levels than in 1997, and contributed to similar end-of-growingseason stubble heights both years.

In rested pastures, mean relative and total elk use remained relatively light and similar across the 3 sampling periods both years (i.e., range $=22-26 \%$ during 1997 ; range $=13-26 \%$ during 1998; Table 1). Corresponding mean stubble heights in rested pastures were also fairly constant across sampling periods during 1997 (i.e., 12,10 , and $12 \mathrm{~cm}$, respectively), but showed a declining trend during 1998 (i.e., 17,16 , and $12 \mathrm{~cm}$, respectively; Table 2 ).

\section{Discussion}

\section{Level of Forage Use}

Whether the Walker Basin Allotment grazing system provided "proper" forage use depended on the metric used. For example, mean 1998 total use in grazed pastures $(61 \%$, Table 1$)$ exceeded levels recommended for semi-arid ranges (e.g., 30-40\%, Holechek et al. 1998); however, residual stubble height for western wheatgrass (Table 2) never fell below the 8-10 cm (3-4 in) minimum recommended by the same authors (Holechek et al. 1998). In rested pastures, mean total elk use $(22 \%$ in 1997 and 26\% in 1998) and end-of-growing-season stubble height $(12 \mathrm{~cm}$ during both 1997 and 1998) were also within recommended limits (Holechek et al. 1998).

Adhering strictly to utilization or stubble height guidelines while ignoring effects of intensity, frequency, and season of use yields an incomplete picture of grazing impacts (Zhang and Romo 1995, Smith 1998). For example, cattle grazing in each pasture occurred only 19 days/year (intensity, frequency) and after seed set or during dormancy, when western wheatgrass is less vulnerable to herbivory (season of use) (Smith 1998). Pastures grazed by cattle 1 year were rested from cattle the following year (frequency) and receiyed relatively light elk use (intensity).

Because total use in rested pastures was nearly the same in June as in October (Table 1), we concluded that most elk use occurred early in the growing season when western wheatgrass was in the vegetative stage (season of use). Perennial grasses tend to be more tolerant of grazing during the vegetative stage compared to the reproductive "boot" stage because meristematic tissue is relatively closer to ground (Frost et al. 1994, Smith 1998).

The sampling technique used may also influence the results obtained. One disadvantage of the paired-plot technique is that use estimates are imprecise unless sample size is very large (Klingman et al. 1943). An attempt in 1998 to decrease paired-plot unit variability within sampling areas by individually matching subsamples was ineffective (Bork and Werner 1999). Additionally, Bork and Werner (1999) suggested that the standard practice of zeroing negative utilization values when using the paired-plot technique could contribute 10 overestimation of forage use on spatially heterogeneous ranges. Negative use values from paired-plot units were zeroed following Werner and Urness (1998). Zeroed paired-plot data in our study were 9 percentage points higher than 
non-zeroed paired-plot data (Halstead 1998); thus, overall results and interpretation would not have changed appreciably had non-zeroed use data been used as suggested by Bork and Werner (1999).

The paired-plot technique has also been shown to overestimate forage production and use due to enhanced moisture conditions within protected plots (i.e., the "microclimate effect"; Grelen 1967, Owensby 1969, Halstead 1998). The microclimate effect may be magnified when birds and small mammals "fertilize" protected plots or when precipitation and the resulting production are above average (Owensby 1969). Stubble height and forage production were higher in 1998; however, 1998 total use in grazed pastures exceeded 1997 use levels despite slightly lower stocking rates in 1998 (i.e., 5.1 vs $6.9 \mathrm{ha} / \mathrm{AUM}$ in 1997 and 1998, respectively). Finally, rougher topography in the northern pastures ( 1 and 2) compared to the southern pastures ( 3 and 4) may have limited cattle distribution in 1998, contributing to the higher use levels and the seasonal decline in stubble heights measured that year.

\section{Elk and Cattle Grazing Patterns}

The grazing system did not provide half of the study pastures with complete rest because elk used all pastures both years of the study. In 1997, relative and total elk use in rested pastures remained slightly below the recommended 30 to $40 \%$ range during all 3 sampling periods (Table 1). In 1998, the same trend in rested pastures held except there was relatively less elk use before cattle grazing (13\%). A decline in 1998 stubble height for both grazed (10 $\pm 0.6)$ and rested $(12 \pm 0.6)$ pastures at the end of the growing season suggested that some elk use occurred in the study area after cattle grazing (Table 2). However, similar forage use estimates made after cattle grazing, and at the end of the growing season during both 1997 and 1998, suggested that elk did not return to the study area in high enough numbers to significantly increase total forage use in either grazed or rested pastures from June to October (Table 1). We therefore conclude that forage manipulation by cattle did not attract elk to cattle-grazed pastures within the same year. We also conclude that elk use was not influenced by previous year's cattle grazing, because elk use prior to the arrival of cattle was about twice as high in pastures 1 and 2 as in pastures 3 and 4 both years, regardless of grazing treatment (Table 1). Corresponding residual stubble heights were slightly lower in pas- tures 1 and 2 compared to pastures 3 and 4 both years (Table 2). Pastures 1 and 2 were near a drainage thought to be used by migrating elk and had more pinyon and juniper cover than pastures 3 and 4 . Thus, elk use patterns were apparently more related to preferences for protective cover, topography, and traditional migration patterns than the grazing system's hypothesized effect on forage regrowth and palatability (Skovlin 1982, Wallace and Krausman 1987, Vavra 1992, Dyke et al. 1998).

\section{Conclusions and Management Implications}

Our study provided local knowledge of cattle-elk forage use and stubble height patterns in central Arizona, which is an essential first step for managers to evaluate whether management practices are achieving resource objectives (McIntosh and Krausman 1982, O'Neil 1985, Cook et al. 1998). Forage use data provides a general idea of the level and patterns of large ungulate herbivory (Miller et al. 1994, Smith 1998). Stubble height data complements forage use and other monitoring data because it is correlated with erosion protection, soil moisture retention, forage regrowth potential, and small animal and insect habitat (Hall and Lindenmuth 1998). Although it appears that the Walker Basin Allotment grazing system promotes proper levels of residual vegetation, a more comprehensive rangeland monitoring program is needed to confirm or refute this assertion (Laycock 1998, Smith 1998). Rangeland trend data (e.g., plant species composition, herbaceous and shrub cover, vegetation structure) would help determine long-term sustainability of forage use or residual stubble height levels.

Because elk foraging on the Walker Basin Allotment was evidently affected more by elk habitat preferences than the grazing system, further field investigations are needed. For example, the relationship between elk and cattle forage use and temporal and spatial distribution on the Walker Basin Allotment may differ at higher or lower elevations and result in different elk use patterns. Manipulative experiments at different elevations are needed to determine whether habitat changes induced by the grazing system (i.e., forage quality and quantity) exert more influence on elk at these elevations than other habitat elements like cover and topography (Vavra and Sheehy 1996, Cook et al. 1998).
Elk and other wild ungulates have the freedom to choose foraging sites that best meet their physiological and behavioral needs. Managers designing dual or multispecies grazing systems should consider how intensity and season of livestock grazing, in combination with local level habitat characteristics and animals' behavioral habits, might influence spatial and temporal movements of wild ungulates (Cook et al. 1998, Unsworth et al. 1998).

\section{Literature Cited}

Alt, K. L., M. R. Frisina, and F. J. King. 1992. Coordinated management of elk and cattle, a perspective-Wall Creek Wildlife Management Area. Rangelands 14:12-15.

Anderson, E. W. and R. J. Scherzinger. 1975. Improving quality of winter forage for elk by cattle grazing. J. Range Manage. 28:120-125.

Bork, E. W. and S. J. Werner. 1999. Viewpoint: Implications of spatial variability for estimating forage use. J. Range Manage. 52:151-156.

Cook, J. G., L. L. Irwin, L. D. Bryant, R. A. Riggs, and J. W. Thomas. 1998. Relations of forest cover and condition of elk: a test of the thermal cover hypothesis in summer and winter. Wildl. Monogr. 62:1-61.

Dyke, F. G., W. C. Klein, and S. T. Stewart. 1998. Long-term range fidelity in Rocky Mountain elk. J. Wildl. Manage. 62:1020-1035.

Frisina, M. R. 1992. Elk habitat use within a rest-rotation grazing system. Rangelands 14:93-96.

Frost, W. E., E. L. Smith, and P. R. Ogden. 1994. Utilization guidelines. Rangelands 16 : 256-259.

Glossary Revision Special Committee. 1989. A glossary of terms used in range management. 3rd ed. Soc. Range Manage., Denver, Colo.

Gordon, I. J. 1988. Facilitation of red deer grazing by cattle and its impact on red deer performance. J. Appl. Ecol. 25:1-9.

Grelen, H. E. 1967. Comparison of cage methods for determining utilization on pinebluestem range. J. Range Manage. 20:94-96.

Hall, F. C. and R. Lindenmuth. 1998. Developing and achieving management objectives on National Forest System lands, p. 47-49. In: Stubble height and utilization measurements: uses and misuses. Agr. Exp. Sta. Oregon State Univ., Corvallis, Ore.

Halstead, L. E. 1998. Monitoring elk and cattle forage utilization under a specialized grazing system in Arizona. M.S. Thesis, The Univ. of Arizona, Tucson, Ariz.

Holechek, J., R. D. Pieper, and C. H. Herbel. 1998. Range management, principles and practices. 3rd ed. Prentice Hall, Upper Saddle River, N.J. 
Interagency Technical Reference. 1996. Utilization studies and residual measurements. BLM National Appl. Resource Sci. Center. Cooperative Exten. Serv., USFS, NRCS, BLM.

Klingman, D. L., S. R. Miles, and G. O. Mott. 1943. The cage method for determining consumption and yield of pasture herbage. J. Amer. Soc. Agron. 35:739-746.

Lacey, J. R. and H. W. Van Poolen. 1981. Comparison of herbage production on moderately grazed and ungrazed western ranges. J. Range Manage. 34: 210-212.

Laycock, W. A. 1998. Variation in utilization estimates caused by differences among methods, years, and observers, p. 17-24. In: Stubble height and utilization measurements: uses and misuses. Agr. Exp. Sta. Oregon State Univ., Corvallis, Ore.

McIntosh, B. J. and P. R. Krausman. 1982. Elk and mule deer distributions after a cattle introduction in northern Arizona, p. 545-552. In: J. M. Peek and P. D. Dalke (eds.), Proc. 10 Wildlife-Livestock Relationships Symposium Univ. of Idaho Forestry, Wildl. and Range Exp. Sta., Moscow, Ida.

Miller, W. H., J. G. Brock, and J. Horsley. 1994. Elk-cattle interaction in central Arizona. Arizona Game and Fish Dep. Tech. Rep. Phoenix, Ariz.

National Oceanic and Atmospheric Administration. 1997. Climatological data annual summary Arizona. Vol. 101(13), ISSN 0145-0387. Natl. Environmental Satellite, Data and Info. Service, Natl. Climatic Data Ctr., Asheville, N.C.
O'Neil, J. 1985. Management strategies and future research on elk in Arizona, p. 35-38. In: G. W. Workman (ed.), Proc. of Symp. on Western Elk Management. Utah State Univ. Agr. Exp. Sta., Logan, Ut.

Owensby, C. E. 1969. Effect of cages on herbage yield in true prairie vegetation. $\mathrm{J}$. Range Manage. 22:131-132.

Skovlin, J. M. 1982. Habitat requirements and evaluations, p. 369-413. In: Thomas, J. W. and D. E. Toweill (eds.), Elk of North America, ecology and management. Stackpole Books, Harrisburg, Penn.

Smith, E. L. 1998. Seasonal effects on the measurement and interpretation of utilization, p. 9-16. In: Stubble height and utilization measurements: uses and misuses. Agr. Exp. Sta. Oregon State Univ., Corvallis, Ore.

Steel, R. G. D. and J. H. Torrie. 1980. Principles and procedures of statistics, a biometrical approach. 2nd ed. McGraw Hill Book Co., New York, N.Y.

Terrestrial Ecosystems Survey of the Coconino National Forest. 1992. USDA/USFS Southwestern Region.

Unsworth, J. W., L. Kuck, E. O. Garton, and B. R. Butterfield. 1998. Elk habitat selection on the Clearwater National Forest, Idaho. J. Wildl. Manage. 62:1255-1263.

Vavra, M. 1992. Livestock and big game relationships. Rangelands 14:57-59.

Vavra, M. and D. Sheehy. 1996. Improving elk habitat characteristics with livestock grazing. Rangelands 18:182-185.
Vavra, M., M. McInnis, and D. Sheehy. 1989. Implications of dietary overlap to management of free-ranging large herbivores. Proc. Western Sect.Amer. Soc. of Anim. Sci. 40:489-495.

Wallace, M. C. and P. R. Krausman. 1987. Elk, mule deer, and cattle habitats in central Arizona. J. Range Manage. 40:81-83.

Wambolt, C. L., M. R. Frisina, K. S. Douglass, and H. W. Sherwood. 1997. Grazing effects on nutritional quality of bluebunch wheatgrass for elk. J. Range Manage. 50:503-506.

Werner, S. J. and P. J. Urness. 1998. Elk forage utilization within rested units of restrotation grazing systems. J. Range Manage. 51:14-18.

Wisdom, M. J. and J. W. Thomas. 1996. Elk, p. 157-182. In: P. R. Krausman (ed.), Rangeland wildlife. Soc. Range Manage., Denver, Colo.

Yeo, J. J., J. M. Peek, W. T. Wittinger, and C. T. Kvale. 1993. Influence of rest-rotation cattle grazing on mule deer and elk habitat use in east-central Idaho. J. Range Manage. 46:245-250.

Zhang, J. and J. T. Romo. 1995. Impacts of defoliation on tiller production and survival in northern wheatgrass. J. Range Manage. $48: 115-120$. 